\title{
doi.org/10.46291/ISPECIJSSHvol4iss4pp350-386
}

\section{A Research on Marketing and Consumer Habits in Konya Jewelry Sector}

\author{
Emre NALÇACIGIL \\ Ahmet Fatih ÖZYILMAZ \\ Dr., Selcuk University, emrenal@ hotmail.com ORCID: 0000-0001-9834-7472 \\ PhD. Can., Selcuk University, fatih_ozyilmaz@hotmail.com, ORCID: 0000-0002-8400-0563
}

\begin{abstract}
More than 50 percent of the world's gold production and more than 90 percent in our country are used in jewelry making. Gold, which has been used for decoration and investment instrument for centuries, continues to be demanded by the people of our country in order to both decorate and saving with a habit stemming from our traditions. Turkey's jewelry sector, which is in the top 5 in the world gold demand and ranked 2nd in gold jewelry exports, currently has 5500 jewelry shops, 20 large jewelry production complexes, 100 wholesale jewelry stores, 40 thousand jewelry shops and 250 thousand employees work in this sector. Jewelry sector has produced for many years with manual labor. Today, the sector has to keep up with the transition to technologyintensive production in order to operate in the world markets and to meet the increasing export demand. The problems of the sector, which has come to a certain place in the world markets and strives for first place, are dealing with greater attention than before. After 1990, the sector was put into a reform process. Necessary institutions for the development of the sector have been put into operation. On the other hand, the development of this industry; While it manifests itself in issues such as branding, product design, technological innovations, marketing strategies, deficiencies in legal regulations damage especially the small-scale jewelry traders. In this study, luxury consumption and hedonic shopping habits are examined by searching literature. In this respect, the phenomenon of consumption was first examined in detail. In the second part, the jewelry sector was explained in all aspects, and then a research was conducted on the consumer habits and the state of the sector with the support of the Konya Jewelers Association.
\end{abstract}

Keywords: Consumer habits, luxury and hedonic consumption, jewelry sector, gold, investment and jewelry, Konya Jewelers Association.

\section{Konya Kuyumculuk Sektöründe Pazarlama ve Tüketici Alışkanlıkları Üzerine Bir Araştırma}

\section{ÖZET}

Dünya altın üretiminin yüzde 50'sinden, ülkemizde ise yüzde 90'ından fazlası mücevher yapımında kullanılmaktadır. Uzun yıllar bir tasarruf aracı ve süslenmek için kullanılan altın, ülkemiz halkı tarafından da geleneklerimizden kaynaklanan bir alışkanlıkla hem süslenmek hem de tasarruf yapmak amaciyla talep edilmeye

Year 4/ 2020, Volume-4, Issue-4 | wwW.ispecjournal.org 
devam etmektedir. Dünya altın talebinde ilk 5 içerisinde yer alan ve altın mücevher ihracatında da 2 . sıraya gelen kuyumculuk sektörümüzde şu an için 5500 kuyumcu atölyesi, 20 büyük mücevher üretim kompleksi, 100 toptan mücevher satış mağazası, 40 bin civarında kuyumcu mağazası bulunmakta ve 250 bin çalışan bu sektöre emek vermektedir. Sektör uzun yıllar el emeği ile üretim yapmıştır. Günümüzde ise sektör, dünya piyasalarında faaliyet gösterebilmek ve artan ihracat talebini karşılayabilmek için teknoloji ağırlıklı üretime geçiş dönemine ayak uydurmak zorundadır. Dünya piyasalarında belli bir yere gelen ve birincilik için uğraşan sektörün sorunlarıyla, eskiye göre daha büyük dikkatle ilgilenilmektedir. 1990 yılından sonra, sektör bir reform sürecine sokulmuştur. Sektörün gelişimi için gerekli kuruluşlar faaliyete geçirilmiştir. Sektörümüzün gelişmesi; markalaşma, ürün tasarımı, teknolojik yenilikler, pazarlama stratejileri gibi konularda kendini gösterirken, yasal düzenlemelerdeki eksiklikler özellikle küçük çaptaki kuyumcu esnafa zarar vermektedir. Bu çalışmada genel olarak lüks tüketim ve hedonik alışveriş alışkanları literatür taraması yapılarak incelenmiştir. Bu bakımdan öncelikle tüketim olgusu ayrıntılı olarak irdelenmiş, İkinci bölümde ise kuyumculuk sektörü tüm yönleriyle açıklanmaya çalışılmış ve ardından Konya Kuyumcular Derneğinin desteğiyle tüketici alışkanlıkları ve sektörün durumu üzerine bir araştırma yapılmıştır.

Anahtar Kelimeler: Tüketim Alışkanlıkları, Lüks ve Hedonik Tüketim, Kuyumculuk Sektörü, Altın, Yatırım ve Mücevher, Konya Kuyumcular Derneği.

\section{INTRODUCTION}

The history of the jewelry business in Anatolia, which has a history as ancient as human history, is about five thousand years old. As a result of the archaeological work done, B.C. in the three thousand years, the first works of goldsmithing activities were observed in Ur city of Mesopotamia. Items from Monarch graves in Ur city cemeteries: necklaces, clock buckles, earrings, musical instruments, such as ornaments were reached (Bilici, 2013: 8-9).

Jewelry is the art of producing all kinds of jewelry or ornaments by processing precious metals and stones and converting these products into works that are used as an investment tool after they are processed. Gold is the first thing that comes to mind when it comes to jewelry. However, other precious metals such as silver and non-mineral origin raw materials are used as raw materials other than gold in the jewelry sector, or their combined forms. In contrast to what is known in the above definition of goldsmithing, it is a craft that is not only bought and sold but also produced and sold from an artistic point of view (www.ticaret.gov.tr, access date: 12.03 .2020$)$.

Almost every civilization that has survived in Anatolia has used gold and worked in accordance with their own way of life. The Seljuks and Ottomans, the two Muslim Turkish states that ruled in Anatolia, made jewelry that reflected their religion and traditional Year 4/ 2020, Volume-4, Issue-4 | WWW.ispecjournal.org 
understanding. The Golden culture in Turks has reached today within the framework of a certain tradition (Kaplan, 2003: 45). From a historical point of view, the start date of the jewelry sector in Turkey is considered to be the year 1461 when the Grand Bazaar was founded. With the establishment of the Grand Bazaar, the developing production, commercial and Human Relations made Istanbul one of the most important centers. In this period, it is considered that the "Ahi" tradition was a system that led the sector. Ahizm, on its own terms, the people who lived in Anatolia in the Seljuk and Ottoman period trade, art, economics to grow them in different vocational areas, such as allowing them morally training, working life, regulating organization on the basis of good human virtues (Erken, 1998: 50). The first development of the jewelry sector in post-Republic of Turkey was implemented in 1930 with the Prohibition of the import and export of gold and other precious metals. In these years, guild organizations were replaced by capitalist production functions. With the disappearance of the guild organizations, Association became the modern organizational model of the present period. Between the 1960s and 1970s, the jewelry sector in Istanbul, especially in the Grand Bazaar, developed and grew, and the number of jewelers increased by 33\% (Köroğlu, Varol and Eceral, 2009: 121-143).

The Istanbul Chamber of Jewelers, one of the most important institutions leading the jewelry sector today, was established as an association in 1971. With the increasing influence of Liberal policies in Turkey, the sector is stepping into an important period in the 1980s. In this period, as Turkey moved into the free economy market, liberalization steps were taken in the gold sector. With this decision, facilities were introduced for the export and import of gold. in 1984 Turkish Central Bank established a gold market in exchange for Turkish currency according to the determination of the value of the exchange rate in arbitrage for the Turkish lira (Kaplan, 2003: 44).

The first exports in the jewelry sector in Turkey were made to Saudi Arabia with 25 kilograms of gold in 1982. At the beginning of the 1990s, the sector started a whole new era due to its efforts to adapt to both branding and international markets. Between 1990 and 2000, the number of employees in the sector nearly tripled, while the added value of the sector to the national economy increased approximately 12 times (Cantekin, 2014: 28).

The establishment of the Gold Exchange in 1995, the jewelry sector, which has more convenient mobility, has become able to supply raw materials at world prices with the establishment of the gold exchange. The fact that gold prices in Turkey are at the world price Year 4/ 2020, Volume-4, Issue-4 | www.ispecjournal.org 
standards started with the establishment of the Istanbul Gold Exchange and imported gold is required to be generally accepted purity and standard at the same time it has been registered (Kaplan, 2003: 26). The biggest breakthrough after these developments in the jewelry sector is the Istanbul Gold Refinery, which was founded in 1996. The Istanbul Gold Refinery was established with the support of the Istanbul Gold Exchange and the Under secretariat of Treasury, thus giving impetus to the development of gold banking and the development of the sector.

The jewelry sector report prepared by the Ministry of Commerce in 2018. according to the export of jewelry made of precious metals in Turkey has increased significantly in the last 10 years. With this increase, Turkey's ranking in the industry has raised and the jewelry sector in Turkey has the capacity to process 400 tons of gold and 200 tons of silver into jewelry every year.

Turkey is among the top 10 countries in the world gold jewelry production, and the world jewelry authorities point Turkey as a rival to Italy. according to the published report by the Department of Commerce, there are approximately 5 thousand manufacturers and 35 thousand retail stores in the sector. Gold jewelry production centers are generally located in Istanbul. In Anatolia, especially in some provinces such as Mardin Midyat, Kahramanmaraş and Trabzon, there is production with traditional lines.

In the sector, $30-40 \%$ of the production is exported, while the rest is sold to domestic consumers, tourists and shuttle traders. Every four tourists who come to Turkey, an average person buys jewelry. About $40 \%$ of the gold jewelry produced annually is also sold to tourists and shuttle traders. Turkey's gold jewelry imports amounted to us \$ 513.7 million in 2017 . (www.ticaret.gov.tr, access date: 06.02.2020).

Although gold is considered as one of the most obvious investment tools in Turkey, it is actually used as an ornamental jewelry, especially preferred by women. For this reason, gold has been shaped according to the culture of that region in every province of Turkey and different models have emerged. Today, it is necessary to work for the formation of institutions that are trying to attract the appreciation of people both as quality and technology and models in order to ensure a regular production and marketing. After this brief introduction, the next section is about consumption phenomenon and the habits of gold consumers in Turkey in general. 
After introduction, in the study, firstly, the phenomenon of consumption will be examined in detail, and in the second part, the jewelry sector will be explained broadly. Then, with the support of Konya Jewelers Association, a research on consumer habits and the state of the sector will be presented.

\section{CONSUMPTION CASE AND ITS IMPORTANCE}

\subsection{Consumption and Consumer Concepts}

Consumption has been one of the subjects that economics is most interested in throughout human history. Investigation of consumer behavior is an issue where economists put a lot of effort. While defining the science of economics; human needs are considered to be unlimited, whereas goods and services that meet human needs are considered scarce. In other words; There is an imbalance between human needs and goods and services that meet these needs. Many consumers live in a society. These consumers have the opportunity to purchase only limited amount of goods and services with limited incomes (Ünsal, 2004: 7).

People, by their psychology; they are in an effort to meet their unlimited number of needs. These inherent characteristics of people are among the determining factors in the increasing importance of the phenomenon of consumption (Bocock, 2005: 33). From this point of view, the human adventure of life is in parallel with the development process of the phenomenon of consumption. However, consumption phenomenon is a process that develops as a result of social and cultural changes of societies (Zorlu, 2006: 26). Adam Smith is considered to be the founder of economics with his famous masterpiece "Wealth of Nations", which he published in the 18th century. In his famous work, Adam Smith emphasized the importance of the phenomenon of consumption (Smith, 1997: 13): The annual engagement of all Nations is the main source of the essential materials for the life that this nation spends every year. This resource consists of the direct product of national labor, or what is purchased through this product from other nations. The concept of consumption; It can be defined as "using final goods and services to satisfy human demands and needs". The benefit of these goods and services must be direct. Consuming a good does not necessarily mean that the good in question will perish. It is also within the scope of the concept of consumption to benefit from a good, gradually or continuously over time (Ünsal, 2004: 8). The benefits of some goods disappear as soon as they are used. For example; When the goods such as bread and tomato are consumed and the goods such as wood are burned, their benefits disappear together with 
their material assets. Such goods are called nondurable goods. Some goods do not disappear in one use, but their benefits can be used for a long time. Durable consumer goods do not disappear in one use, but benefit level decreases with each use. Services are also used to meet needs, such as goods. The haircut of the barber is a service, it is a service for the doctor to examine the patient. Unlike goods, services disappear when they meet the needs. It is not possible to accumulate services like goods (Parasiz, 2000: 10). Consumption is the primary purpose of economic activities. However, it is the last stage of economic activities. The fact that one good meet human need indirectly, that is, the use of another good in the production is not in the concept of consumption. For example; It is not a consumption to use electricity for production in a factory. Because the utility of electricity was not destroyed here, it was transferred to other goods produced at the factory as a result of the quality change. Whereas, if electricity was used in our homes and its benefit was completely destroyed, consumption would be counted. The concept of consumption is mainly used in economics in three meanings. First; It is the satisfaction of the consumer who uses a good. Latter; are real consumption tools that are offered to a consumer as goods and services. In this sense, consumption is the use of goods and services to meet current needs. The third is; This is the amount of money spent for consumer goods in cash (Avralığlu, 1976: 12). Based on this definition, we can say that the concept of consumption has three elements. Firstly; Some goods and services are selected for consumption. Secondly, these goods and services are used. The last element of consumption is to ensure satisfaction as a result of using goods and services (Çalıskan, 2003: 8). A consumer is a person or community that uses goods and services to meet their needs or provide satisfaction. Family is taken as the consumer unit in economics. Economics treats the family as the smallest organized economic decision unit. However, regardless of how the decisions regarding consumption in the family are taken, these decisions are expressed as if they are the decisions of a single person (Türkay, 2007: 9). In microeconomic theory, it is accepted that a consumer acts in a way that he maximizes the benefit he gains in the face of the goods and services he encounters in the market. When individuals make a decision to consume, they buy some goods and services, and spend money on consumption. All the decisions taken by consumers in the name of consumption affect economic life. The decisions that individuals make as consumers affect the economy at both micro and macro levels. 
The theory of consumption behavior in microeconomics examines the factors that affect the consumption decisions of individuals and households. These examinations are made according to some assumptions. Among the accepted assumptions; it is assumed that the consumer is rational, consumer preferences do not change in the examined period, the consumer spending income is fixed and the market price is data (Türkay, 2007: 8).

Based on these assumptions in microeconomics, it is analyzed how to maximize consumer benefit. On the other hand, macroeconomics examines the total consumption expenditures and the importance and effects of the expenditures made for this purpose in the economy. The founder of modern macroeconomics is considered Keynes. The famous work of Keynes, "Employment Interest and General Theory of Money", which was written in 1936, is accepted as the beginning of macroeconomic analysis. Since classical economists did not see the need to examine the total demand in the period until Keynes, no economic analysis related to the total consumption, which is the most important element of the total demand, was conducted (Kazgan, 2004: 220).

Generally, economists were based on spending as "purchasing consumer goods" and did not dwell on the phenomenon of consumption, they were keen to share and generate more income.

\subsection{Needs, Scarcity and Choice}

The need can be defined as things that delight people when they are met, and give pain and sadness when they are not met. According to another definition, it is a sense of abstinence that people feel and try to meet in their material and spiritual self.

Human has many and diverse needs. The concept of need is classified in different ways. Classifications such as compulsory and non-compulsory needs, material, physiological, psychological and cultural needs can be made. The generally accepted classification method is the classification that accepts the needs that are necessary for a person to continue his life, and those that do not comply with these as non-compulsory or traditional needs (Ünsal, 2003: 5$6)$.

Needs have several features. One of them is that the needs are very diverse and unlimited. Over time, needs change and their number is increasing. The number of needs is lower in economically developed countries than in economically developed countries. Another feature of the needs is their continuity. For this reason, some needs must be met repeatedly, eating 
and drinking needs can be given as examples. Another feature of the needs is that they lose their intensity as they are met (Öztürk, 2010: 7). The scarcity of resources and the infinity of needs and the existence of alternative areas of use raises the problem of "choice". It is an economic problem that the needs are ranked according to severity, which groups of people are given priority in benefiting from the benefits of goods and services, and the choice of alternative uses of scarce resources (www.gigapedia.com).

\subsection{Consumption, Savings and Investment}

In a country, the income obtained after the income tax given to the state by the people living in that country in one year is called usable income. Disposable income equals total consumption and savings. Income not spent for consumption is considered as savings.

Although consumption is not within the scope of spending, the reason for mentioning savings is that saving is accepted as the non-consumable part of disposable income (Ünsal, 2005: 136).

No matter who receives the revenues in an economy and what service is obtained, it is spent for two purposes. It is used to meet daily needs and for consumption expenditures. Latter; to build production capacity, that is, for investment spending. Consumption expenditures; are the expenditures that people make to meet their current needs.

Investment expenditures cover all expenditures except consumption expenditures. Therefore, in terms of employment theory, investments are not necessarily an expenditure that increases the accumulation of capital (Aren, 1992: 37).

It is not easy to separate consumption and investment expenditures. Consumption spending is about using a final good and making use of it. Investment spending, on the other hand, is an increase in capital goods and stocks. In order to distinguish the two types of expenditures, it is necessary to look at the economic functions of the goods, not the physical properties of the expenditure. If a good is used for consumption, consumption expenditure should be counted, if this good is used in the production of another good or service, investment expenditure should be counted. For example; If a dishwasher was purchased for washing dishes at home, consumption goods should be accepted as investment goods if it was purchased for use in a restaurant (Avralı̆̆glu, 1976: 28).

Year 4/ 2020, Volume-4, Issue-4 | WWW.ispecjournal.org 
An important relationship between consumption and investment; The unconsumable income, savings, is the financing of investments. In the long term, savings have an important place in terms of financing investment expenditures on economic growth (Ünsal, 2005: 597).

\subsection{The Relationship between Consumption-Economic Growth and Employment}

In modern employment theory, effective demand is the main factor that determines income and employment level. This is because the full or incomplete use of production capacity is determined by the total demand.

Consumption expenditures constitute the most important part of effective demand. Therefore, examining the factors affecting consumption expenditures is very important in terms of modern employment theory. John Maynard Keynes expressed this situation as follows (Keynes, 1936: 89): The ultimate aim of our analysis is to reveal what determines the employment volume. The fact that consumption has an income and employment-generating feature in the economy through spending is a new development. In the theory of economics, production and sharing have been mainly focused on since classical economic thought, and capital accumulation has been focused on development. Analysis of consumption expenditures as a rotating force of income and employment wheel was made possible by modern employment theory. The most important feature of consumption expenditures is that they are stable. After talking about the scientific infrastructure of the concept of consumption, we will touch upon the phenomenon of savings and luxury consumption, hedonic shopping, other than consumer behavior, purchasing motivation and physiological needs.

\section{CONSUMER BEHAVIOR-PURCHASING BEHAVIOR-HEDONISM}

\subsection{Consumer Behavior}

In this section, consumption and purchasing behavior will be handled in general and then the concept of hedonic shopping will be explained. It can be said that marketing of goods and services is not just an economic activity, there are many different reasons affecting people's purchasing behavior. So, consumer behavior; It can be explained as a scientific field of thought that analyzes the currents and factors that react to these processes in which all people choose products and services, opinions or experiences, use them for money, shop and sell or change after experience. Consumer behavior examines not only what happens during shopping, but also before and after purchasing, experiences about these processes and various factors. Consumer behavior is a function of internal and external variables. Knowing these Year 4/ 2020, Volume-4, Issue-4 | WwW.ispecjournal.org 
variables and their relationships allows them to have an idea about how the consumer will behave. External variables include the economic, social and geographical environment of the individual, his profession, educational background, and income level. Internal variables are physiological and psychological variables; determines the wishes and needs of the consumer and plays the final role (Şen, 2007: 68). As always, some assumptions and quantities specific to this field should be investigated in explaining consumer behavior. It is possible to combine the characteristics of consumer behavior in seven basic areas (Odabaşı and Barış, 2010: 30).

* Consumer behavior is a flagellated act.

* Consumer behavior is a mobile process.

* Consumer behavior consists of various activities.

* Consumer behavior is complex and varies in terms of time adjustment.

* Consumer behavior is related to various roles.

* Consumer behavior is affected by environmental factors.

* Consumer behavior is personal.

\subsection{Buying Behavior}

Shopping movements of consumers can be examined in three clusters: shopping, reactive shopping, and planned project shopping. The vast majority of products bought by consumers consist of goods purchased due to routine or otherwise habits. The purchaser owns the behaved behavior and wants to obtain a good without much examination. Many of the products taken routinely are very affordable, uncommon to apply, and can be found in a wide variety of products everywhere. Characteristic purchasing, on the other hand, appears when an individual purchases a product with a movement, even though there is no idea of purchasing, which is related to the general lifestyle, character, and intuitive features. The possibility of purchasing high-priced products, which is necessary at the end of this kind of shopping movement, is more evident. In the case of a planned purchase, the user or consumer is more conscious. Planned purchasing behavior is more frequently observed in products such as cars and households with high costs and low purchases. (Kaptan, 2011: 122). 


\subsection{Hedonism: hedonistic and utilitarian consumption}

They must meet their needs in order to sustain their lives in terms of physical, communicative and spiritual. The need to enjoy is the natural state created from the birth of man. The person turns to activities and products that can give pleasure in order to enjoy and be happy. The concept of pleasure is an area that most thinkers are interested in. They have suggested close ideas from some points about pleasure to different points. The philosophical view that sees pleasure as the principle of ethics and finds the value of life in pleasure is called pleasure. (Özdemir, 2007: 70). So, what is pleasure first? As the term of philosophy, "feeling intuitive or spiritually happy about anything" is everything that is generally liked, pleasing, and makes the person feel more pleasant (http://www.tdk.org.tr/TDKSOZLUK).

Pleasure; It is a very sweet and enjoyable fetish sensation and satisfaction, which lies beyond happy pain and as a spiritual being, which comes from having and obtaining something that pleases and attracts us. Socrates showed his disciples that happiness can be achieved by looking for good and wanting it. What is goodness? Kireneli Aristippos, the student of Socrates, has developed the concept of "hiding" by claiming that the best beauty is to enjoy.

While finishing the section on consumption phenomenon, the next section is an overview of the jewelry products and jewelry sector in Konya.

\section{JEWELRY PRODUCTS AND JEWELRY SECTOR}

Anatolia is extremely important in the transition from the era of household and hunting goods that make life easier to the jewelry process. During the archaeological excavations in Alacahöyük, the presence of five thousand years of consumption work and hand tools shows how old the jewelry was.

Jewelery, an art dominated by creativity and labor, was born and developed in Anatolia. With the modern age, technological developments dragged jewelry to the westernized industrialized countries (Turgut, 2003: 51).

The Turkish jewelry industry has made great strides over the years. Considering the developments in the world market consumption trends in the jewelry industry, Turkey has been one of the few industry players, known as the global economy.

In 2002, becoming the rapidly growing world jewelry market gold bullion prices Although a severe contraction of the increase in Turkey by exporting the country near the gold jewelry to 
face in 2008, the Turkish jewelry for recognition by the international community has shown a great success. Today, the jewelry industry is a giant family with around 2,500 manufacturer companies, over 30,000 jewelry stores and over 200,000 staff.

The Turkish jewelry sector emerges as a sector that increases its popularity and success day by day after the 1990s. The sector had the opportunity to meet 25 kilos of gold made to Saudi Arabia in 1982 for the first time with exports (TOBB, 2007: 52).

Official gold jewelry exports, which started with 12.7 million USD in 1992, reached a figure exceeding 1.5 billion USD in 2008. These official figures on sales made outside the suitcase trade and tourist sectors are also exchange gain of 3 to 3.5 billion USD to Turkey's economy Given.

\subsection{Jewel, Jeweler and Jewelry Concepts}

In the current dictionary, Jewel; ornaments made of jewelry, precious metals and stones. Jeweler; the person who makes or sells jewels, bracelets, earrings and the like, of precious metals and stones. Jewelry is a craft that requires the processing of precious metals with a fine work, shaping and polishing precious ornaments, framing with a monter, or drilling to make arrays and using many production techniques until reaching the final product (Çıtak, 2006: 39).

Today, jewelry is a profession formed by using advanced technology, with the accumulation of knowledge and aesthetic values of humanity from ancient times to today. Designing, producing and presenting products that will help people feel better are the working areas of the jewelry profession (Kaya, 2006: 30).

The history of jewelry is as old as the history of mankind. Although jewelers are the first to come to mind when dealing with goldsmiths, goldsmith is a profession that is used to create ornaments by processing gold and silver mines (Zeytin, 2004: 2).

The fact that gold and silver were obtained from nature very early in the history led to the gain of art in production. Today, the artistic feature of jewelry still remains valid. It is possible to come across the first examples of jewelry art in the early ages of history. Many ornaments such as earrings, necklaces, and hairpins were found during the excavations. It is known that gold and silver were processed in the city of Sumerians in Mesopotamia between 4000-3500 BC. In many world museums, gold and silver ornaments from the Sumerian, Egyptian, 
Minoan, Mycenaean, Finick, Assyrian and Etruscan civilizations are exhibited (Ayter, 1996: $1)$.

The artists in the early ages, with the support of the sovereign powers, have worked through thousands of years of experience and knowledge, simple tools, creativity and practical solutions, and created an in-depth technical development. In fact, the works of art that have survived to the present day are far ahead of the results achieved proportionally (Türe and Savaşçın, 2000: 26). The craftsmen of ancient times developed the technology of thinning like dice by beating pure gold. Ancient Egyptian burial finds indicate that before 1700 BC, 0.001 $\mathrm{mm}$ thin leaves could be made. Continuing its development with the advancement of human history, jewelry has shown itself especially in Egypt, Mesopotamia and Anatolia. With the influence of trade routes in the states established in Anatolia, jewelry making has grown considerably.

\subsection{Jewelry Products: Precious Mines and Precious Stones}

Precious metals, are important financial products traded in the world and in Turkey. The main precious metals are gold, silver and platinum, besides the demand for investment in these mines, there is also demand from other sectors where they are used as raw materials, especially for the jewelry sector.

Precious metals are obtained from the mines of a limited number of countries in the world. Gold, silver and platinum markets in the world have developed especially in countries where the supply and demand of these mines are high.

Although gold is the first factor that comes to mind when it comes to jewelry, it is inevitable to turn gold into products together with precious metals. which reached about 168 billion US dollars in the world market volume diamond jewelry industry also exhibit growth above the world development in Turkey. Gold market, the world three times in the last twenty-five years growing up, showed a two-fold improvement in Turkey four years. Reaching a market of 1 billion USD, the sector is expected to grow forty percent in the coming period (Saraç, 2009: 24).

\subsubsection{Precious Mines}

Mines such as gold, silver and platinum are called "precious metals". These mines are metals that human beings have known and used since ancient times. 
The use of gold, silver and platinum group metals in industry is increasing with a variety of technological developments in the world (İme, 2007: 59). Precious metals are referred to as precious metals or noble metals because they are resistant to oxidation and corrosion and are rare. When used specifically in gold, silver and platinum production, they become very soft and wear out quickly. For this reason, substances called precious metals are added while adjusting to prevent and harden abrasion.

\subsubsection{Gold}

Gold has always applied some kind of magical power to people throughout the history of mankind because of its extremely scarce and immediately evident beauty. Although the exact date and place cannot be known precisely, the first meeting of humanity with this yellow metal probably dates back to very ancient times. Gold is very rarely found in nature. It usually contains silver and sometimes other metals. Most of the gold in the world is obtained from yellow metallic material in the soil (Aras, 1996: 11). This alloy, which is harder and lighter than pure gold, is called electrum (Sar1, 2006: 1). The second important compound in nature is claverite gold tellurium which contains $43 \%$ gold. Its less important compound is silvanite and petzite (Aras, 1996: 11). Gold, which does not mix with other mines, continues to exist in the mountains, where granite and quartz fill the cracks in the earth's crust, in thin veins and remains in place with millions of years of heat trapped (Bernstein, 2008: 19). The symbol of gold is "Au" and comes from the Latin word aurum. This word means glowing dawn in Latin. The atomic weight of gold, which is a 1B group of noble metals, is 197 and its atomic number is 70. Gold has $1.063^{\circ} \mathrm{C}$ melting and 2,600 ${ }^{\circ} \mathrm{C}$ boiling point, 25 units of hardness and 42 units of flexibility. Gold is a mineral suitable for processing with its durability of 119 kilograms / square meter. A plate of 119 square meters can be made from 1 kilogram of gold (Saraç, 2009: 25). Also, gold is a very dense substance. Its specific weight is 19.3 grams / cubic centimeter. It can fit about 20 kilograms of gold in a place where 1 liter of water fits (Turgut, 2006: 4).

Gold is a very valuable metal with its properties such as easy shaping, chemical resistance, corrosion resistance, oxidation resistance, high thermal and electrical conductivity and reflective properties (Saraç, 2009: 25-26).

Gold is a mine that has increased its importance from past to present, has been an important value storage tool for centuries, has been used in making money and jewelry, and has been 
used in the industrial field as a result of technological developments in recent years. While gold was the basis of a monetary system between 1870 and 1930, it was a key reserve instrument with a full conversion to the dollar between 1944 and 1973.

However, the liquidity role that gold has played in the past has lost its effect in today's conditions and gold has gained a property rather than a commodity. The main use of pure gold is ingot making. More than half of the gold available in the world is stored in the United States in the form of ingot. As it is known, the second area of use is jewelry production in jewelry (Saraç, 2009: 26).

Other Uses of Gold: (Aras, 1996: 13)

- It is used in coating materials such as wood, metal and leather.

- It is used in the electrical and electronic industries.

- It is used in dental filling and coating.

- Thin gold plates that can be reversed by reflecting $98 \%$ of infrared rays are used in space suits and on the surface of artificial satellites.

- In medicine, gold salt is used to treat artery inflammation and leprosy. Radioactive gold is effective in cancer treatment.

\subsubsection{Silver}

Silver is a whitish gray metal. Because of this feature and brightness, silver was named "argertum" in Latin. Argertum means white and bright (Aslan, 2001: 422). Silver has an atomic number of 47 , atomic weight of 107.88 , and its symbol Ag. The density of silver is 10.5 grams / cubic centimeter, the melting point is $960^{\circ} \mathrm{C}$ and the boiling point is $2.212^{\circ} \mathrm{C}$ (Zeytin, 2004: 18). Pure silver value is accepted as 1000 in international markets. Commercial silver has a minimum of 999 purity. The unique properties of silver; It is durable, beaten and easily shaped, electrical and thermal conductivity, sensitive to light, reflecting light and being able to react easily (Kaplan, 2004: 47). The fact that it has so many features and its price is quite low compared to other precious metals makes silver preferable in many applications. In the jewelry sector, silver is very much needed to adjust the purity of the gold. For this reason, it is inevitable for silver to be traded in countries with gold trade.

Usage Areas of Silver (Aslan, 2001: 423)

Year 4/ 2020, Volume-4, Issue-4 | WWW.ispecjournal.org 
- Ornamental items

- Electric and electronic

- Coatings (e.g. mirrors)

- Soldering in engineering studies and jewelry

- Photography

It is believed that the use of silver in different forms and forms in societies' cultures protects people from evil eyes, evil and diseases.

\subsubsection{Platinum}

Platinum group metals, consisting of palladium, rhodium, iridium, ruthenium and osmium, are found in the same mine vein in nature. Platinum group metals are classified as precious metals due to their limited availability in nature. Platinum is an element indicated by the symbol "Pt" in the periodic table, the atomic number is 78, the atomic weight is 195.09. Its melting point is $1,768,3^{\circ} \mathrm{C}$ and boiling point is $3,825^{\circ} \mathrm{C}$. Platinum is one of the most valuable metals known in the world. Platinum is therefore King XV. It was described by Louis as a king-worthy metal (http://tr.wikipedia.org/wiki/Platin). The largest platinum producer country in the world is South Africa. $88 \%$ of the reserve is located in this country and approximately $80 \%$ of the production is covered by this country. Therefore, platinum supply varies depending on the political structure of South Africa and the labor movement. Platinum demand is mostly industrial. Platinum price acts in interaction with other precious metals. Platinum is preferred by investors, especially because of the price trend in the same direction as gold. $50 \%$ of the board is used in industry, $40 \%$ in jewelry and $10 \%$ in investment. Japan ranks first in demand for platinum jewelry. Platinum group metals, together with the jewelry sector, in the fields of chemical, petroleum refining, automotive, electrical and electronic, ceramic and glass industry, dentistry and medicine, due to their strong resistance to oxidation and corrosion, high melting temperature, insolubility in acid solubility and high electrical conductivity. has a lot of use. platinum in Turkey, industry, automobile industry and is used in the jewelry industry. The demand in the jewelry industry is in the form of wedding rings. Platinum jewelry production is made by 20-25 jewelers in the Grand Bazaar (Kaplan, 2004: 51). Platin is also traded on the Istanbul Gold Exchange along with other precious metals. 


\subsubsection{Precious Stones}

Precious stones are formed by carbon, aluminum, silicon, calcium and magnesium elements that are abundant in nature. These stones were formed under various physical and chemical conditions, especially under high pressure.

Precious stones are examined in three groups according to their usage areas.

- Industrial Ornamental Stones: It is used in various industry branches such as rhinestone and crystal quartz.

- Gem Stones: These are precious ornaments such as emeralds, rubies, diamonds and diamonds, which are mounted on jewelery.

- Ornamental Stones: These are the stones used for the decoration of precious and commemorative goods (İme, 2007: 98).

\subsubsection{Emerald}

Emerald is a green colored, transparent and very precious stone as a type of beryl mineral. Emerald, which dates back to $1650 \mathrm{BC}$, has been used as jewelry for centuries. In some cultures, emerald is a traditional gift for the wedding anniversary (http://tr.wikipedia.org/wiki/)

The hardness degree of the emerald is about 8. Colorless, white, bluish green, greenish yellow, pinkish orange, dark and bright ones are called emerald, bluish gray ones are called "aquamarine". Carat is used as the weight unit of the emerald.

\subsubsection{Ruby}

Ruby is a precious stone with a melting point of $2,050^{\circ} \mathrm{C}$. It can be in various shades of red. It is caused by the chrome element inside that gives the red color to the ruby. Ruby has a hardness rating of 9 .

Apart from red, there are also sky-colored and yellow-colored ones. The yellow one is not precious. The value of ruby increases as its transparency increases. The sky color is called sapphire, the red or pink color is called a tulip. The most famous ruby type is drop ruby. This ruby is clean, transparent and half hazelnut domed. Carat is used as the weight unit of ruby. 


\subsubsection{Diamond and Brilliant}

The diamond consists of crystallized pure carbon and is transparent like crystal. It is a very precious stone because it is scarce in nature. When it comes to the earth with carbon lava that dissolves into gas at very high temperatures in the magma layer in the center of the world, it meets water at the volcano's skirts and crystallizes by hardening with sudden cooling. These transactions are estimated to be around 900 million years ago in the world. Although the raw material and form of formation of the diamond is known, it is not possible to produce it by human beings (İme, 2007: 99).

The diamond is available in pink, blue, and even black. Large pieces of white diamond are processed and made of diamonds. However, diamonds are not obtained from every diamond. The raw diamond turns into a diamond or diamond according to its shape. When the raw diamond is cut up to 12 to 37 facets, the diamond becomes the brilliant when cut down. The cut of the diamond is more difficult. So, its art to make it is harder. Almost half of the diamonds removed are used in the industry and the remaining part is used in jewelry and other business areas (İme, 2007: 100-101).

The most important features of the diamond; It reflects the sun rays completely and in seven colors and is one of the hardest materials in the world. The main difference between diamond and brilliant is; Brilliant is whiter and brighter than diamond. In order to make the diamond look bright and luminous, a paint called foil is placed underneath and then transfix it on to the ornament.

The weight of diamond and brilliant is carat. The diamond sector has an important place in the jewelry market. In the last few years in Turkey showing $25 \%$ growth in its market sector, it has led them to turn to diamond jewelry businesses. Turkey has reached the level of 1 billion USD diamond jewelry market. (Saraç, 2009: 30-31).

\subsubsection{Pearl}

The mussels and oysters that live in the bottom of the seas open and close foreign matter with a special secretion that they secrete because they cannot remove the sand particles entering their bodies. The object formed as a result of wrapping the sand all around is called "pearl". Natural or natural pearls are spontaneously formed in nature, and those formed by knitting special bodies placed in oysters fed in special pools are called "cultured pearls". Pearls are especially used as necklaces in all kinds of ornaments. Apart from the known white and pink Year 4/ 2020, Volume-4, Issue-4 | WWW.ispecjournal.org 
color, black pearl is also encountered, although it is very rare. But black pearl is very valuable.

Pearls come mostly from the following countries: Japan, Australia, Indonesia, Myanmar, China, India, Philippines and Tahiti. Japan controls about $80 \%$ of the world pearl market. Australia and China follow Japan, respectively (İme, 2007: 103).

\subsection{Jewelry Sector}

People have paid great attention to embellishment since very ancient times. Ancient peoples who lived in Anatolia, gold, silver, ivory, coral, mother-of-pearl, agate, seashells and jewelry made with precious stones such as rings, necklaces, bracelets, chains, anklets, earrings and brooches will often bring good luck and blessings believing that they will protect themselves from evil, they used it in various parts of their bodies. In addition to using precious metals and stones as mentioned above, it has been used as a symbol of beauty, wealth and nobility throughout history (Fidan, 2005: 67).

Gold mining, management and jewelry production in Anatolia started five thousand years ago. During the excavations in Alacahöyük, a five-thousand-year-old jewelry workshop and hand tools were found. Civilizations living in Anatolia have achieved perfection in this art. Brooches, necklaces, pins, bracelets and the like, which are made of precious materials such as gold, silver, agate, quartz crystal in the prince tombs especially in Troy, Eskişehir and Alacahöyük regions, are works of art. Again, the finds obtained in the excavations carried out in the West, East and Southeast Anatolia reflect the advanced level of Anatolian people in design and casting in the 2000s. After the Bronze Age, Assyrian merchants, who established trade colonies in Anatolia between 2000 and 1200 before Christ, took gold, silver and copper mines from here instead of the goods they brought from Mesopotamia. Lydian King Karun founded the first refinery and mints in the Aegean region in order to print new money from the products he earned from gold mines in $630 \mathrm{BC}$. Thus, Lydia was the first civilization in the world to use money. By the arrival of the Seljuks in Anatolia, it is seen that the ancient Asian forms and traditions were continued in the jewels of the nomadic or settled Turkish tribes (Türe, Savaşçın, 2000: 9). The Ottomans took over the legacy of an extremely rich tradition of jewelry, which was shaped by invasions and migrations that lasted for millennia.

In this sense, the only thing they can do is to bring the jewelry to its peak. This was accomplished successfully. Ottoman jewelry reflected the experience of the huge lands that 
the country expanded with the ancient artisanal accumulation it took over (Turkishtime Sectors, 2003: 67).

After the conquest of Istanbul, the production of gold jewelry in the Ottomans started when Fatih Sultan Mehmet placed the Armenians known for their craftsmanship in jewelry. jewel and jewelry production in Istanbul is concentrated around the world's first closed shopping center "Grand Bazaar". The center, which is in the development process of the jewelry industry after the Republic, was once again the Grand Bazaar. The Grand Bazaar has traditionally hosted the manufacturer and retailer segment for many years (Kaya, 2006: 33). jewelry industry sector in Turkey, began in 1983 after the cancellation of the ban on the export laws. Thus, the sector was opened to foreign world markets. Turkey working towards the Middle East until 1986, after the experience and confidence Turkish jewelers have begun to prove themself and opened in 1987 the United States market (Özbek, 2009: 11).

Regarding imports of gold bullion, The Central Bank was allowed in 1985. In 1989, The Central Bank created the gold market in order to bring the raw material cost of the jewelry industry to the same level with other jewelry manufacturers in the world. After this development, "DAK" opened an office in Istanbul.

In 1995, "IAB" was established the same year, imports of gold bullion authority have been given to the Central Bank of the Republic of Turkey is a member of the IAB on the monopoly of private sector representatives. These initiatives allowed the sector to buy gold at world prices. Turkey, the world production of gold jewelry bride at the last point is among the world's top five countries. In gold jewelry production data for 2007 indicates that Turkey's rise to second place. A research of DAK (World Gold Council) reveals that buys gold, jewelry one out of every three tourists in Turkey. This is the proof that Turkey has become a country of gold and jewelry (Özbek, 2009: 13).

The ounce price of gold, which has been steadily rising for many years, has reached a record level by exceeding 1000 USD in 2009. Despite the global economic crisis began to show its effect in the last quarter of 2008, data for Turkey's exports of precious metals and jewelry 2008 was in pretty good condition (the www.immib.org.t).

Precious metals and jewelry exports, 2,18 \% of Turkey's total exports in 2018. There has a share. The Turkish jewelry field has gained an important place in the international field with the initiatives it carries out. The most obvious symbol of this is that the World jewelry 
Confederation held the 2009 World jewelry Congress in Istanbul. In 2010, 80 tons of gold were imported, most likely due to the ongoing impact of the 2008 financial crisis.

Turkey as a country in the world in 2011, while in 11th out valuable jewelry exports, ranks second after Italy in the jewelry exports. Approximately $40 \%$ of the annual production rate is exported, and the rest is sold to domestic consumers, tourists and luggage traders. About one out of every three tourists coming to Turkey is to buy gold jewelry and jewels. Approximately half of the gold jewelry produced annually is sold in tourism and to those who trade luggage. Turkey's gold jewelry exports amounted to about 2 billion US dollars in 2018. (www.immib.org.tr) The main exporting countries are the United Arab Emirates, Iraq, Kazakhstan, the Russian Federation, the United States, Lithuania, Germany and Italy. Turkey's gold jewelry imports amounted to about 500 million US dollars in 2018. The main importing countries are Italy, United Arab Emirates, Hong Kong, Indonesia, the United States, Spain and South Korea.

\subsection{Organizations Operating in the Jewelry Sector}

The Turkish Jewelry sector has been one of the most important players in the world gold sector with its performance in manufacturing, exporting, branding and merchandising in the last twenty years. In this position of the sector in addition to manufacturing and exporting companies, the contribution of the organizations operating in the sector is quite high. Thanks to these organizations, the process of gaining a voice in the Turkish jewelry sector in the world has gained a great speed. The number of companies operating in the field of jewelry sector also increases with the rapid growth experienced in the sector. The main institutions serving the jewelry sector are listed below (Saraç, 2009: 13-21):

* General Directorate of mint and stamp printing

* Istanbul Gold Exchange

* World Gold Council: DAK

* Istanbul precious metals and jewelry exporters Union

* Istanbul Gold Refinery: IAR

* Istanbul Chamber of Goldsmiths: IKO

* Kuyumcu Kent in Istanbul 


\subsubsection{General Directorate of Impregnation and Stamp Printing House}

One of the ancient and deep-rooted institutions of the jewelry sector is mint. Although the history of the mint goes back centuries, the first established Mint was established around the Beyazit Mosque by Fatih Sultan Mehmet to meet the money needs of the state, which expanded rapidly with the conquest of Istanbul, and it was considered the beginning of the establishment of the Turkish Mint. Although the establishment date is not known precisely, the first foundation date of 1467, which is the date of the first Turkish gold printed by Fatih Sultan Mehmet on his behalf, is accepted. The General Directorate of Mint and Stamp Printing House, which operates under the Under secretariat of the Treasury, takes into account the diversity of goods produced by the latest technology mints in the world, including coins, republic golds, medals and engagement, medallions, souvenir, various products, official It produces seals and stamps, visas and stamps, valuable papers, passports, identity cards, international family cards and identities of various government agencies. Mint, Turkey also allows entering and exiting made of precious metals and stone ornaments from the analysis and controls on the export and import of doing. In this context, precious metal analyzes are carried out in the laboratory with high standards. As the mint serves as an official setting house, it is responsible for authorization and supervision by allowing the establishment of private setting houses (www.darphane.gov.tr).

Production of the Republic gold of the Mint was influenced by the worldwide price increases and the global financial crisis. In 2006, around 61 tons of production increased to about 62 tons in 2007 and remained around 58 tons in 2008. Since October 2008, when the global financial crisis started to be effective, a significant decrease in demand is observed (www.darphane.gov.tr).

As a revolving fund enterprise, The Mint increases its profits by committing to the product range in commemorative products, taking into account the product range produced by the advanced mints in the world. The organization also made an important contribution to the treasury by increasing its 2006 profit from 18 million TL to 32 million TL in 2007 and 41 million TL in 2008. The mint also takes part in many fairs organized at home and abroad within the framework of annual programs. The most important of these is the Istanbul International Jewelry, Jewelry, Silver, Watch and Materials Fair (Turkishtime Sectors, 2003: 11). 


\subsubsection{Istanbul Gold Exchange: İAB}

It contains values and social inclusion of the financial system in Turkey's gold with a power of decisive economic potential has been realized in terms of a long process. The addition of gold to the financial system as an economic value arose at the end of the liberalization process in the economy in 1980 and after. Gold sector to take its place in the financial system, the opening of Turkey's economy to international markets, by supporting the sector, which has been promoting the development of capital movements and the mobilization of new institutions and instruments. The increase in exports in the jewelry sector since 1990 has enabled gold exports to take place in the international arena (Yanık, 2007: 40).

Following the legislative studies, the gold exchange, which aims to improve gold banking, to bring the gold stock in the hands of the people to the economy and to support the jewelry sector, entered service on July 26, 1995. With the launch of the IAB, the informal gold market gained an institutional structure and a safe environment was offered to investors. In addition, competitive price formation was enabled. With the establishment of IAB, besides the Grand Bazaar economy, gold jewelry and jewelry market gained a more organized structure and an international dimension. Product costs at competitive prices appeared at a real level. (Kaplan, 2004: 58).

\subsubsection{World Gold Council: DAK}

The World Gold Council is a non-profit association founded in 1987 by the world's largest gold producer companies. Its members include consumers, investors, industrialists, traders and official institutions as well as gold producers. Society is in the center of London, particularly in the United States, China, Japan, United Arab Emirates, Turkey and India has branch offices (www.gold.org).

The main areas of activity of the World Gold Council are to promote the use of gold in jewelry, investment and industry. The Council spends millions of dollars of incentive and development to increase the demand for gold jewelry (Fidan, 2005: 61).

The main purpose of the World Gold Council is to increase the interest in gold consumption in the countries, as well as to support the domestic jewelry sector and to contribute funds (Ç1tak, 2006: 143). The objectives of DAK are as follows (Subaş1, 1997: 198): Increasing the use of gold as jewelry, investment tool and industrial raw material; bringing the gold standard and quality to a certain level; transfer technical information to the gold investor; 
developing new investment tools based on gold; to encourage investment institutions to buy gold for their portfolios; to work on the development of the jewelry sector and to support new designs in business administration; to work on statistical information. To accomplish these goals, the council has a gold jewelry department and investment departments. Each department determines the support points to be given by following the developments in the world in the fields of activity. It also provides training and broadcasting services. To support the positive developments in the gold market and to facilitate the accelerated development in 1991, has opened its representative office in Istanbul, Turkey. The representative has been providing consultancy on jewelry production technology since 1991, preparing publications on the subject and conducting seminar studies. The council carries out joint activities with gold jewelry manufacturers that have completed the technical and design infrastructure of the sector and carries out marketing activities (Turkishtime Sectors, 2003: 14).

Since 1993, DAK has been advising the Capital Markets Board on liberalization of the gold sector. The World Gold Council's Turkey representative, designers, manufacturers, retailers and consumers in order to strengthen the relationship between "Trend Book" has published a book entitled. In addition, it undertakes the task of promoting award winning designs in domestic and foreign markets with jewelry and design competitions (Kaya, 2006: 28).

The World Gold Council continues its efforts to reduce taxes on gold and its products in Turkey, to improve quality and design in business, and to improve marketing activities in order to increase consumers ' interest in gold.

\subsection{4. İstanbul D. M. M. B.}

Istanbul Precious Metals and jewelry Exporters Union was established in July 2003 as an organization affiliated to the Undersecretaries of Foreign Trade and within the General Secretariat of the Istanbul Minerals and Metals Exporters' Associations.

\subsubsection{Istanbul Gold Refinery: IAR}

There are many institutions engaged in gold refinery and gold processing activities in the world. It is possible to list the activities of the refining industry as follows: filtering the gold element that has just been released to nature, re-refining scrap gold, damaged or low purity ingots and ingots produced by unapproved refineries. Gold manufacturing for use in jewelry and other industries. Gold bars production (Kaplan, 2004: 51). 
In addition to the gold exchange, the establishment of the gold refinery is also a must in mobilizing the gold potential (Aslan, 1999: 46). For this purpose, the Treasury and Turkey in 1996 with the support of Istanbul Gold Refinery was founded. IAR ensures that the gold and scrap gold produced all over the world are refined and processed in the IAB (Kaya, 2006: 27).

\subsubsection{Istanbul Jewelers Chamber: İKO}

When Istanbul is recognized as the center of jewelry in Turkey, one of the most important organizations in the sector is IKO. The foundation of the Istanbul Chamber of Goldsmiths is the "Association of Manufacturers and Goldsmiths of touristic crafts" which was established in 1971 on behalf of the jewelry manufacturers and dealers working in Istanbul. Since the number of members of the association reached a large number in a short period of time, a new organization was needed. With the development of the jewelry sector, the association became a chamber in 1994 (www.iko.org.tr).

The purpose of the establishment of the IKO is to provide rapid response and response to the holistic requirements of artisans and artisans, to simplify their functioning and to encourage the advancement of the profession (Çıtak, 2006: 141).

By not limiting its services to more than four thousand members operating in Istanbul, the Istanbul Chamber of Goldsmiths plays a very important role in the development and promotion of the jewelry sector in national and international markets. IKO's work includes finding new markets for its members, directing them to export, supporting participation in national and international fairs (Kaya, 2006: 26).

It continues to support the sector in training qualified personnel, which have an important role in the development of the jewelry sector, by opening courses such as vocational and foreign languages, and by contributing to the departments related to jewelry in vocational high schools and vocational schools. Gold, silver, platinum and palladium analysis can be done in a two and a half hour period in the Istanbul Jewelers' Room setting house established in 2006. In March of 2008 Istanbul Chamber of Jewelry, it has introduced the first fully equipped laboratory to Turkey with diamonds agreement with an international diamond laboratory. İKO continues to seek solutions to the problems of the sector with sectoral and bureaucratic dialogues (Istanbul Jewelers Chamber, 2009: 43). 


\subsubsection{Kuyumcukent}

Four hundred years of history the jewelry industry Turkey must carry out production with a more appropriate technology infrastructure in more complex structures by the success of the world's changing conditions and industry. Since the Grand Bazaar, which has been the center of the sector since the Ottoman era, does not allow for a modern production structure, a structure that will meet the needs of the sector was needed (Kaplan, 2004: 61-62). Kuyumcu kent was born with the idea of developing and improving the infrastructure of the jewelry field, creating mass production areas based on jewelry manufacturing and peaceful with human health. Today, it has all kinds of services that are needed for jewelers and wedding shopping on the ground floor. The institution, which houses over a hundred stores, serves in Istanbul as a large complex with jewelry manufacturing workshops and work offices on the upper floors. After discussing the concept of consumption and jewelry sector, the next section discusses the interviews with 86 jewelry tradesmen serving Konya.

\section{A BILATERAL INTERVIEW ON THE JEWELRY SECTOR IN KONYA PROVINCE}

\subsection{Method}

In this section, the situation of the Gold and jewelry sector in Konya region was analyzed in social and financial terms based on oral discussion, but in the activity, the gold and jewelry area's financial support to the region is analyzed and it is aimed to show the socio-economic side. For the purpose of the examination, the type of survey was applied as a way of obtaining data based on obtaining information from the priority Center. Data related to the survey results were collected and analyzed and interpreted with the statistical program. The prepared survey collected concrete information about the recent situation in the field of gold and jewelry, their economic characteristics, their impact on communication networks and monetary life and their relevance to the state. Survey questions during the first phase to be ready for your first scales in the academic literature on the subject (Arnold and Reynolds "reasons that motivate shopping hedonic scale" developed by Richins and Dawson, "Materialism Scale"), articles, and dissertations, various books and then analyzed the projects recently implemented Konya Jewelers Association, gold industry sector employees provided by consultation with important issues about to be included in the survey. In order to speed up the process and to obtain more reliable answers, the questionnaire was conducted by face-to- 
face interview method. Survey questions were distributed to 350 establishments affiliated with Konya Goldsmiths Association and data was obtained based on answers from 86 business owners and senior managers who agreed to the interview. Some of the questions included in the survey are closed and open-ended questions prepared using the $5 \mathrm{~s}$ Likert scale. The other questions in the survey are the ranking questions and the grading scale.

\subsection{Results}

According to the questionnaire, the contribution of the jewelry sector to the Konya economy was evaluated as more than about forty-seven percent of the participants, while over 40 percent contributed at a medium level.

Whether gold is an alternative to foreign currency and foreign exchange products is an important subject of study today. Consumers were asked whether gold is an alternative to foreign currency. The proportion of participants who see gold as an alternative to foreign currency in Konya reaches $81.4 \%$, while $18.6 \%$ think it may be an alternative. Among the consumers who responded to the questionnaire, there are no people who think that gold cannot be an alternative to foreign exchange and foreign exchange products.

Table 1. Demographic Information of the Respondents

\begin{tabular}{|l|l|l|}
\hline Age & Number & Ratio \\
\hline $20-29$ & 11 & $12,8 \%$ \\
\hline $30-39$ & 23 & $26,7 \%$ \\
\hline $40-49$ & 31 & $36 \%$ \\
\hline Over 50 & 21 & $24,4 \%$ \\
\hline Education Status & Number & Ratio \\
\hline Primary School & 3 & $3,5 \%$ \\
\hline Secondary School & 22 & $25,6 \%$ \\
\hline High School & 52 & $60,5 \%$ \\
\hline University & 9 & $10,4 \%$ \\
\hline
\end{tabular}


Table 2. Contribution to Konya Economy

\begin{tabular}{|l|l|l|}
\hline Options & $\mathbf{N}$ & $\mathbf{R}$ \\
\hline Very Much & 4 & $4,7 \%$ \\
\hline Much & 40 & $46,5 \%$ \\
\hline Average & 38 & $44,2 \%$ \\
\hline Insufficient & 4 & $4,6 \%$ \\
\hline
\end{tabular}

Table 3. The Level of Alternating Gold against Foreign Money Exchange in Konya

\begin{tabular}{|l|l|l|}
\hline Options & N & $\mathbf{R}$ \\
\hline $\begin{array}{l}\text { Yes, it is definitely an } \\
\text { alternative }\end{array}$ & 11 & $12,8 \%$ \\
\hline Yes, it is alternative & 59 & $68,6 \%$ \\
\hline Can be an alternative & 16 & $18,6 \%$ \\
\hline
\end{tabular}

Table 4. Periods of Gold Market Revival in Konya

\begin{tabular}{|l|l|l|}
\hline Options & $\mathbf{N}$ & $\mathbf{R}$ \\
\hline Dec - Jan - Feb & 1 & $1,2 \%$ \\
\hline Mar - April - May & 1 & $1,2 \%$ \\
\hline June - July - August & 79 & $91,9 \%$ \\
\hline Sep - Oct - Nov & 2 & $2,3 \%$ \\
\hline Other & 3 & $3,5 \%$ \\
\hline
\end{tabular}

Year 4/ 2020, Volume-4, Issue-4 | wwW.ispecjournal.org 
The gold and jewelry market is generally more dynamic at various times in our country. This questionnaire was asked to reflect which seasons were more intense. Answers related to this question are given in table 4 . The survey proves to a large extent that a large amount of gold is sold in Konya in the summer season. Approximately ninety-two percent of consumers think that the gold market is more active in the summer months. In face-to-face interviews, it is stated that the reason for the increasing number of customers in the summer are with the influence of the weddings held in the summer and our citizens living abroad those who return to their homes for holiday purposes.

Table 5. Credit Card Usage Rate in Gold Exchange

\begin{tabular}{|l|l|l|}
\hline Options & $\mathbf{N}$ & $\mathbf{R}$ \\
\hline Very Common & 7 & $8,1 \%$ \\
\hline Common & 55 & $64 \%$ \\
\hline Rare & 16 & $18,6 \%$ \\
\hline Not Common & 2 & $2,3 \%$ \\
\hline Not used at all & 6 & $7 \%$ \\
\hline
\end{tabular}

The habit of shopping with credit cards has become a commercial payment method that has found a lot of use with the spread of online shopping in our country. It also has an important place in all markets today. Online jewelry shopping is not yet a very common area in our country. The reasons for this are the fast variable gold prices and the sellers who want to protect themselves from price increases, bank commissions and bank blockage times, and the fact that the prices are very high in online shopping and the sector is based on mutual trust with face-to-face shopping.

It is obvious that in the purchases made today, the credit card is used as a payment tool in a very important part of the money payments. It was asked to provide a numerical data on the intensity of the use of the credit card in gold and jewelry purchases. Answers to this question 
are given in table 5. About the use of credit cards in gold and jewelry shopping in Konya, approximately seventy-three percent of respondents responded widespread and very common, while twenty-eight percent stated that credit card use was low.

Table 6. Gold Credit Usage Rate

\begin{tabular}{|l|l|l|}
\hline Options & $\mathbf{N}$ & $\mathbf{R}$ \\
\hline Rarely & 3 & $3,5 \%$ \\
\hline Sometimes & 13 & $15,1 \%$ \\
\hline Never & 70 & $81,4 \%$ \\
\hline
\end{tabular}

Gold loan usage asset is a little-known loan type, this question was asked to discuss how intensive its use is and the answers regarding this question are given in table 6. Gold loan means gold loan support for goldsmith trades, the main means of production and sales, Interest rates preferred only by those who are engaged in gold trade are generally very low, but the unit indexed in gold prices is calculated on the basis of gold gram, and it is a type of loan in some banks, especially in TEB. Eighty-two percent of the respondents stated that they did not use gold credits at all, while fifteen percent stated that they used less, and rarely used three and a half percent. This is an indication that the participants did not buy gold from the banks by credit method, most likely they bought gold with their savings. When we examine the most preferred gold types in Konya, we see that bracelets stand out as the most admired and preferred gold jewelry with approximately seventy-four percent. The second row is followed by rings and necklaces with a share of about thirteen percent. In the third row of the order, the earrings stand out with forty three percent, while the earrings are followed by twenty-three and a half wedding rings and necklaces. According to the general result obtained here, while bracelets take the first place in gold jewelry sales in Konya, rings, earrings, wedding rings, necklaces follow respectively. 
Table 7. Reasons for Demand for Gold According to Participants

\begin{tabular}{|l|l|l|}
\hline Options & $\mathbf{N}$ & $\mathbf{R}$ \\
\hline Saving & 14 & $16,3 \%$ \\
\hline Ornamental & 6 & $7 \%$ \\
\hline Prestige & 30 & $34,9 \%$ \\
\hline Traditions & 36 & $41,9 \%$ \\
\hline
\end{tabular}

According to the participants, traditions are the most important reason for women to exchange gold for Konya. Forty-two percent of women buy gold for traditions. The ratio of women who buy gold for prestige is thirty-five percent, and that of those who buy gold for investment is about seventeen percent.

Table 8. Return of Gold over Other Investment Tools

\begin{tabular}{|l|l|l|}
\hline Options & N & R \\
\hline The Gain is Very Much & 11 & $12,8 \%$ \\
\hline Much than Others & 57 & $66,3 \% \mathrm{q}$ \\
\hline Almost Same & 17 & $19,8 \%$ \\
\hline Less than Others & 1 & $1,2 \%$ \\
\hline
\end{tabular}

Again, according to the participants, while seventy-nine percent of those who make savings in gold are of the opinion that the return of gold is higher than other investment instruments, twenty percent believe that their gains are the same and only about one percent of the gold is less. 


\section{CONCLUSION AND EVALUATION}

It is obvious that the answers received are not surprising considering that the people of Konya are conservative, humble but generally fancy and willing to look like wealthy. It is not very satisfactory that the jewelry trade area has an average contribution to the city economy. Moreover, it is a fact that the transaction capacity well above the city average and the economic income added to many jewelry tradesmen among the top 20 tax recorders according to the data of Konya Chamber of Commerce remain in the region. Official data show that there is around one and a half tons of gold consumption per year in Konya and its provinces, while survey findings show that consumption is much more than one and a half tons with a response of seventy-two percent. In fact, thirty-four percent of the respondents stated that consumption is more than two and a half tons annually, not one and a half tons. We are of the opinion that the difference between official data and survey data is caused by informal transactions. Seventy-two percent of respondents think that consumers commonly use credit cards in their gold purchases.

Another remarkable point is that although there is a high demand for gold especially in marriage events in the society where the use of credit card is very widespread, it is observed that there is not much credit from banks for these golds. An obvious consequence of this is the application of gold purchases through installments on credit cards and borrowing on various goods that are still valid in the region. In the meantime, cash TL is preferred primarily in gold and jewelry shopping payments, followed by credit cards and foreign currency. When the sociocultural conditions are analyzed, it is observed that the demand for gold is generally concentrated in the months of June-July-August. This situation is explained by the fact that the weddings are held both in seasonal conditions and in the summer months when the harvest is held in Konya region, which has an economic structure based on agriculture, and the number of weddings increases by the weather being held in open areas such as hot and country weddings. Not only for weddings, but also because gold is considered as an investment tool, it can be explained as the habit of investing in gold because of the social safety reasons of people and the unstable economic situation in which the local people who receive a lot of money. Also taking time off from their jobs during the summer months our citizens living abroad to come to visit their homeland and often their savings in Turkey, compared with the price of gold is more affordable abroad are effective in getting here. 
While traditions come to the fore among the reasons for their intense demands especially for women in Konya and its provinces, a very similar view is also considered to be taken for the purpose of dignity. The view that it was taken for investment has a very low rate of six percent. One data that can support these views is that the percentage of survey respondents who stated that the gold received at weddings can be between one and three kilograms. In some high-income families, there are participants stating that this amount can increase up to 7 kilograms, which is much more. According to the participants, the purchase of such a large amount of gold is due to the fact that two-thirds of women see gold as life insurance for religious and social reasons. As a matter of fact, ninety percent of the participants state that in the event of a separation after the wedding, the gold remains as a religious necessity by the girl named as Mehir. We think that this explains a little more why the girl's side demands so much gold in marriages. Another factor in the high demand for gold jewelry is that the people generally consider the gains of gold as more than other investment tools. In this respect, gold is seen as a definite alternative especially against foreign exchange and other investment instruments.

While the survey shows this data, Gold always remains an economically safe port. As it is known, while gold and silver jewelry from four thousand years ago can find coins, no exchange or commercial exchange tool of the past has been found as a means of exchange. For these reasons, it is common in Turkish society to say "get goods like gold". In addition, even if the gold under the pillow does not contribute to the economy, it is a very common form of investment for these reasons. As it is already seen in the survey, the only subject of the mock stock in our country is products like gold and pearl.

In the commercial gold sector, great progress was made compared to the pre-Özal government period, that is, after the year 1980, legal regulations were made and direct gold imports were allowed. Thus, the gold private sector has developed day by day and has ranked second in world exports after Italy. The sector is about to complete the transition to technologyintensive production. And it has managed to create brands around the world. Branded gold production and gold jewelry dealership system are adopted, preferred and developed within the country.

This study aims to give a general information about the jewelry sector with the necessary explanations about the subject from the literature for an overview of the jewelry sector in Konya. Our research is a one-on-one interview technique with the support of Konya Chamber Year 4/ 2020, Volume-4, Issue-4 | WWW.ispecjournal.org 
of Commerce and Konya Jewelers Association, which all jewelers operating in Konya are affiliated with. The limitations of our research are that it is based on interpretation and experience qualitatively and not only on an approved scale, but only in the center of Konya.

\section{REFERENCES}

Akınc1, Mustafa (2009). İKO made a sound with its services in 2008. Gold News Magazine, $170,183-197$

Akit, Hasan (2005). Tim Design Council was established to guide the branding. Gold News Magazine. 148, 5 - 17

Aras, Nuri (1996). Modern Jewelery. Istanbul: Fatih Ofset

Aren, Sami (1992). Employment, Money and Economic Policy (Tenth Edition). Ankara: Savaş Publishing.

Aslan, Servet (1999). Gold and Gold Transactions Accounting, Istanbul: IAB Publications.

Aslan, Servet (1999). Gold and Silver Transactions Accounting (Second Edition). Istanbul: Turkmen Bookstore.

Aslan, Servet (2001). Gold and Silver Transactions Accounting for Intermediary Institutions,

Banks, Commercial Enterprises. Istanbul: Turkmen Bookstore.

Ayter, Adil (1996). Jewelery Professional Knowledge and Jewelery Art. Istanbul: Asgold Publishing

Bernstein, Paoul (2008). The Power of Gold: The Extraordinary History of a Passion, Translated by Levent Konyar. Istanbul: Scala Publishing.

Çıtak, Serdar (2006) The Story of Gold 24 Carat, Istanbul: Support Publications.

Erkmen, Tahir and Yüksel Ceyhan (2008). A Study on Investigation of Consumers' Shopping Behaviors and Demographic and Socio-Cultural Features. İzmir Ege Academic View Magazine. 14, 20 - 50

Fidan, Ebru (2005). Gold-Jewelery Sector and Jewelery Accounting Accounting. Sakarya: Master Thesis, T.C. Sakarya University Institute of Social Sciences.

IAB (2003). Istanbul Gold Exchange and Precious Metals Legislation. Istanbul: Istanbul Gold Exchange Publications, Publication No: 8.

IAB (2002). Istanbul Gold Exchange in the Turkish Finance Sector, Istanbul: Istanbul Gold Exchange Education Publications, Publication No: 1. 
İme, Mehmet (2007). Jewelery Business and Accounting. Istanbul: Istanbul Chamber of Certified Public Accountants. Publication No: 79.

Kaplan, Kemal (2003). Jewelery and Gold. Istanbul: Istanbul Chamber of Commerce Publications, Publication No: 43

Kaplan, Kemal (2004). Jewelry and Gold in Turkey. Istanbul: Istanbul Chamber of Commerce Publications, Publication No: 2004-50.

Kaplan, Kemal (2004). Jewelry and Gold in Turkey, Istanbul: Istanbul Chamber of Commerce publications. Publication No: 2004-50.

Karayiğit, Ahmet (2004). The Importance of Design in Jewelery. İzmir: İzmir Chamber of Commerce publications, Research and Professions Development Directorate Bulletin.

Karayiğit, Ahmet (2004). Gold Istanbul 2004 Fair Report, Gold News Magazine. 145, 20 - 51

Kaya, Saban (2006) Working Conditions in the jewelry sector in Turkey (Istanbul Grand Bazaar in the example), Sivas M.Sc., T. C. Cumhuriyet University Institute of Social Sciences.

Kazgan, Gazi (2004). Economic Thought or Evolution of Political Economy (11th Edition) Istanbul: Remzi Bookstore.

Keynes, John (1936). The General Theory of Employment, Interest and Money, UK: McMillian Publishing.

Mucuk, İbrahim (2004). Marketing principles. Istanbul: Turkmen Bookstore.

Odabaşı, Yener and Barış Gendal (2012). Consumer Behavior (Second Edition) Istanbul: MediaCat.

Özbek, Honor. (2009) "We Can Be the World Leader in the Jewelry Sector", İzmir: Arge Bulletin, İzmir Chamber of Commerce. 95, 5 - 35

Özkan, Gazi (2010). Effects of Brand Perceptions in Consumer Behavior and An Application, Istanbul: Master Thesis, T.C. Istanbul University Institute of Social Sciences.

Parası, İlker (2000). ABC of Economics (Fourth Edition), Bursa: Ezgi Bookstore.

Sağlam, Hazım (1992). Gold File Istanbul: Rıhtım Caddesi Monthly Stock Exchange Bulletin, Year: 2, Number: 14 .

Scott, June (1990). Great Blow to The Leak. Istanbul: Kapital Magazine.

Saraç, Fehmi (2009). Supervision of Stock Accounts in Jewelery Sector and Jewelery Businesses, Edirne: Master Thesis, T.C. Trakya University Institute of Social Sciences. 
Sar1, Ahmet (2006). Investigation of the Effect of Grain Shrinkage on Deep Drawing in Gold Alloying. Istanbul: Master Thesis, T.C. Yıldız Technical University Institute of Science.

Olive, Crocus. (2004). An Application for the Problems and Solution of the Jewelry Sector, Kütahya: Master Thesis, T.C. Dumlupınar University Institute of Social Sciences.

Smith, Adam (1997). Wealth of Nations. Translators: Ayşe Yunus, Mehmet Bakırcı, Istanbul: Alan Publishing.

Subaş1, Tahir (1997). Money Supply Relationship Between Gold and gold in Turkey's Main Area Economic Development Alternative Solutions. Istanbul: Unpublished Doctoral Thesis, T.C. Marmara University Institute of Social Sciences.

Tarakçı, Tahir (2007). We are in the second place after jewelry in Italy. TOBB. Istanbul: Economic Forum Magazine, January 2007, 15 - 18

Toraman, Cahit (1997). The Role of the Istanbul Gold Exchange in Transferring Gold and Capital Markets as an Investment Tool, Malatya: Ph.D. Thesis, İnönü University Institute of Social Sciences.

Turgut, Seher (2006). Phase Cost System and An Application in the Jewelry Sector. Istanbul: Master Thesis. T. C. Istanbul University Institute of Social Sciences.

Turgut, Emre (2003). The Journey of Turkish Gold. Turkish Time Sectors Magazine, 25, 5 45 .

Türe, Alim and Savaşçın, Yılmaz. (2000). The Birth of Jewelery, Istanbul: Goldaş Kültür Yayınları.

Burn, Ihsan (2007). Turkey as an Alternative Investment Gold Use of Economics (Analysis of the Istanbul Gold Exchange Trading). Istanbul: Unpublished Doctoral Thesis, T.C. Istanbul University Institute of Social Sciences.

Yükselen, Cem (2006). Marketing: Principles-Management. Ankara: Detay Publishing. Internet:

Enfal Islamic Information Page. Electronic Data Distribution System, http://www.enfal.de/socialbilimler/t/044.htm (11.04.2019)

General Directorate of Mint and Stamp Printing House. Electronic Data Distribution System, www.darphane.gov.tr (11.04.2019)

GoldNews Magazine Official Website. Electronic Data Distribution System, http://www.goldnews.com.tr/Turkce/yazilar.asp?yaziid=309\&sayiid= $=(05.04 .2019$ 
Goldnews Magazine Official Website. Electronic Data Distribution System, http://www.goldnews.com.tr/Turkce/yazilar.asp?yaziid=584\&sayiid= (05.04.2019)

System, www.immib.org.tr (10.04.2019)

Istanbul Jewelers' Chamber. Electronic Data Distribution System, www.iko.org.tr (10.04.2019)

Jewelery Exporters Association. Electronic Data Distribution System, www.jtr.org.tr (11.04.2019)

Koza Gold Joint Stock Company. Electronic Data Distribution System, http://www.kozaaltin.com/upl/goldprospecteurpoe.pdf (10.06.2019)

Kuyumcu Kent Official Web Site. Electronic Data Distribution System, www.kuyumcukent.com.tr (10.04.2019)

Secretariat General of Istanbul Mines and Metals Exporters' Associations. Electronic Data Distribution

Turkish Language Institution Official Web Site. Electronic Data Distribution System, http://www.tdk.org.tr/terimler/kuyumculuk (02.06.2019)

World Gold Council. Electronic Data Distribution System, www.gold.org (21.04.2019)

Web Free Encyclopedia. Electronic Data Distribution System, http://tr.wikipedia.org/wiki/Platin (01.06.2019)

Web Free Encyclopedia. Electronic Data Distribution System, http://tr.wikipedia.org/wiki/Yakut (10.06.2019)

Web Free Encyclopedia. Electronic Data Distribution System, http://tr.wikipedia.org/wiki/Z\%C3\%BCmr\%C3\%BCt_maden (12.06.2019) 